\title{
YIELD AND QUALITY OF STRAWBERRY FRUITS FERTILIZED WITH BOVINE BIOFERTILIZER ${ }^{1}$
}

\author{
ELISANGELA MARIA DOS SANTOS ${ }^{2}$, THALES VINÍCIUS DE ARAÚJO VIANA², GEOCLEBER GOMES DE \\ SOUSA $^{3 *}$, BENITO MOREIRA DE AZEVEDO ${ }^{2}$, JOÃO GUTEMBERG LEITE MORAES ${ }^{3}$
}

\begin{abstract}
The objective of this study was to evaluate the effect of different doses of bovine biofertilizer on yield and post harvest of the strawberry crop in different growing environments. The experiment was carried out in two cycles of production, in Fortaleza, Ceará. The experimental design was in randomized blocks, arranged in subdivided plots, where the plots were of three cultivated environments (A1 = protected environment with screens, cold-water spraying, and white floor; A2 = environment with full sun, cold-water spraying, and white floor; A3 = environment with full sun, no cold-water spraying, and grey floor). The subplots consisted of five doses of biofertilizer $(\mathrm{D} 1=0,0, \mathrm{D} 2=500, \mathrm{D} 3=750, \mathrm{D} 4=1000$ and $\mathrm{D} 5=1250 \mathrm{~mL}$ plant $^{-1}$ week $^{-1}$ ), with five replications. In the two-year period, the dose was higher in the protected environment of the weed type, with nebulization and on the white floor, at the dose of $500 \mathrm{~mL}_{\text {week }}^{-1}$ plant $^{-1}$ in the first cycle and $325 \mathrm{~mL}$ week plant $^{-1}$ in the second cycle. The dose of bovine biofertilizer of $1250 \mathrm{~mL}^{-1}$ week $^{-1}$ plant $^{-1}$ promotes a longer duration and duration of the first cycle. During the second cycle, as the bovine biofertilizer doses of 585 and 620 provide higher and lower output than the protected environment. The environment without nebulization and on the floor without painting, the best soluble practices $\left({ }^{\circ}\right.$ Brix $)$ in relation to the protected environment of the type screened and a full sun with nebulization.
\end{abstract}

Keywords: Fragaria x ananassa duch. Organic Input. Postharvest.

\section{PRODUTIVIDADE E QUALIDADE DE FRUTOS DE MORANGUEIRO ADUBADOS COM BIOFERTILIZANTE BOVINO}

RESUMO - Objetivou-se avaliar o efeito de diferentes doses de biofertilizante bovino na produtividade e na pós-colheita da cultura do morango em diferentes ambientes de cultivo. O experimento foi desenvolvido, em dois ciclos de produção, em Fortaleza, Ceará. O delineamento experimental foi em blocos ao acaso, arranjados em parcelas subdivididas, onde as parcelas foram três ambientes de cultivo $(\mathrm{A} 1=$ ambiente protegido do tipo telado, com nebulização com água gelada (temperatura variando entre 18 e $20{ }^{\circ} \mathrm{C}$ ) e sobre piso branco, $\mathrm{A} 2=\mathrm{a}$ pleno sol, com nebulização com água gelada e sobre piso branco, A3 = a pleno sol sem nebulização e sobre piso concretado sem pintura) e as subparcelas, cinco doses de biofertilizante (D1=0,0; D2=500; D3= 750; D4=1000; e D5= $1250 \mathrm{~mL}_{\text {planta }}{ }^{-1}$. semana $^{-1}$ ), com cinco repetições. Nos dois anos, a produtividade foi maior no ambiente protegido do tipo telado, com nebulização e sobre piso branco, na dose de $500 \mathrm{~mL}$ semana $^{-1}$ planta $^{-}$ ${ }^{1}$ no primeiro ciclo e $325 \mathrm{~mL} \mathrm{semana}^{-1}$ planta $^{-1}$ no segundo ciclo. A dose de biofertilizante bovino de $1250 \mathrm{~mL}$ semana $^{-1}$ planta $^{-1}$ promovem melhor diâmetro e comprimento do fruto dutante o primeiro ciclo. Durante o segundo ciclo, as doses de biofertilizante bovino de 585 e 620 proporcionam maior comprimento e diâmetro do fruto, respectivamente, no ambiente protegido do tipo telado, com nebulização e sobre piso branco. O ambiente a pleno sol sem nebulização e sobre piso sem pintura, apresentou melhores sólidos solúveis ( ${ }^{\circ}$ Brix) em relação ao ambiente protegido do tipo telado e a pleno sol com nebulização.

Palavras-Chave: Fragaria $x$ ananassa duch. Insumo orgânico. Pós-colheita.

\footnotetext{
${ }^{*}$ Corresponding author

${ }^{1}$ Received for publication in $03 / 17 / 2017$; accepted in 08/08/2018.

Paper extracted from the doctoral thesis of the first author.

${ }^{2}$ Department of Agricultural Engineering, Universidade Federal do Ceará, Fortaleza, CE, Brazil; emsufc@gmail.com - ORCID: 0000-0001 -7230-1644, thales@ufc.br - ORCID: 0000-0002-2294-7225; benito@ufc.br - ORCID: 0000-0003-0722-6371.

${ }^{3}$ Institute of Rural Development, Universidade da Integração Internacional da Lusofonia Afro-Brasileira, Redenção, CE, Brazil; sousagg@unilab.edu.br - ORCID: 0000-0002-1466-6458; gutemberg.moraes@unilab.edu.br-ORCID: 0000-0002-3340-2191.
}

Rev. Caatinga, Mossoró, v. 32, n. 1, p. 16 - 26, jan. - mar., 2019 


\section{INTRODUCTION}

Strawberry (Fragaria $x$ ananassa Duch.) belongs to the Rosacea family; it is produced and appreciated in most regions of the world and is one of the most economic important small fruit species (OLIVEIRA et al., 2006). According to Mazaro et al. (2013), strawberry crops have socioeconomic importance in the South and Southeast regions of Brazil; it is an alternative of income for small farmers. Strawberry is used for fresh consumption and in the food processing industry. The average fruit yield of strawberry crops in Brazil is $30 \mathrm{Mg} \mathrm{ha}^{-1}$, but it can reach more than $60 \mathrm{Mg} \mathrm{ha}^{-1}$ in high-technological areas (REISSER JÚNIOR, 2015).

Technologies for strawberry production has been contributing to meet the quantitative and qualitative demand of farmers and consumers (HENZ, 2010). The fruit yield of strawberry varies significantly depending on the edaphoclimatic conditions of the growing region (thermal amplitude), and physiological (less stomatal resistance) and genetic (cultivar) factors of the plant (CAMARGO et al., 2010). The great variation of climatic conditions and the increasingly demanding consumer market have caused many producers to search for new production technologies. Protected environments are more advantageous to grow strawberries when compared to field conditions; they protect the crop from wind, hail, rain, frost, and low temperatures, minimize occurrence of diseases and attack from pests, and provide better conditions for the plant growth, increasing their fruiting development, and production for commercial purposes (COSTA et al., 2011; DIAS et al., 2015).

According to Reis et al. (2012), protected environments for crops are used intending to increase fruit yields and improving the quality of agricultural products by mitigating seasonal environmental variations in the production area, and reducing the adverse effects of excessive rainfall, incidence of solar radiation, and air temperatures.
The use of organic sources for soil fertilization combined with protected environments is a sustainable alternative for increasing productivity of agricultural crops. Cattle manurebased biofertilizer have been used satisfactorily for this purpose in recent years as an economic, environmental alternative to chemical fertilizers because it favors the natural cycling of nutrients and is a carbon source for agricultural crops (PENTEADO, 2007). These biofertilizer are liquid compounds produced in aerobic or anaerobic conditions with mixed organic material (e.g. fresh manure) and water (VIANA et al., 2014), they provide essential nutrients to the soil (VIANA et al., 2013) and improve the productivity of crops (DIAS et al., 2015).

In this context, the objective of this work was to evaluate the effect of different rates of a cattle manure-based biofertilizer and different environmental conditions on fruit yield and postharvest quality of strawberry plants.

\section{MATERIAL AND METHODS}

The experiment was conducted at the experimental area of the Department of Agricultural Engineering of the Federal University of Ceará, in Fortaleza, CE, Brazil $\left(03^{\circ} 45^{\prime} \mathrm{S}, 38^{\circ} 33^{\prime} \mathrm{W}\right.$, and altitude of $19.6 \mathrm{~m}$ ), in two crop seasons (2013 and 2014). The first crop season was in the dry season (September to December 2013), and the second crop season was in the end of the rainy season (May to August 2014). The climate of the region is Aw', tropical rainy, according to the Köppen classification, with high temperatures, and rainy season mostly in the autumn. The climatic conditions of the experimental area were monitored by automatic weather stations installed in the environments evaluated. The mean and the relative measures of measurement are shown in Table 1.

Table 1. Monthly average air temperature and relative humidity.

\begin{tabular}{ccccccc}
\hline \multirow{2}{*}{ Year } & \multicolumn{3}{c}{ Air temperature $\left({ }^{\circ} \mathrm{C}\right)$} & \multicolumn{3}{c}{ Relative air humidity $(\%)$} \\
\cline { 2 - 7 } & E1 & E2 & E3 & E1 & E2 & E3 \\
\hline $2013^{\#}$ & 28.22 & 29.86 & 30.09 & 69.66 & 68.65 & 66.27 \\
$2014^{\# \#}$ & 27.76 & 28.04 & 29.43 & 71.39 & 70.83 & 69.9 \\
\hline
\end{tabular}

\# = means from September to December; ${ }^{\# \#}=$ means from May to August. E1 = protected environment with screens, coldwater spraying, and white floor; E2 = environment with full sun, cold-water spraying, and white floor; E3 = environment with full sun, no cold-water spraying, and grey floor.

Strawberry seedlings of the cultivar Oso Grande were transplanted into 11-liter pots containing substrate at the ratio 4:4:2 (sandy humic soil, coarse sand, and organic compound), spaced $1 \mathrm{~m}$ $\times 1 \mathrm{~m}$. The chemical characteristics of the substrate presented $19.16 \mathrm{~g} \mathrm{~kg}^{-1}$ of organic matter, $0.16 \mathrm{mmol}_{\mathrm{c}}$ $\mathrm{dm}^{-3}$ of nitrogen, $26.3 \mathrm{mmol}_{\mathrm{c}} \mathrm{dm}^{-3}$ of calcium, 0.11 $\mathrm{mmol}_{\mathrm{c}} \mathrm{dm}^{-3}$ of potassium, $45 \mathrm{mmol}_{\mathrm{c}} \mathrm{dm}^{-3}$ of sodium, $0.34 \mathrm{mg} \mathrm{dm}^{3}$ of phosphorous, and $\mathrm{pH}$ of 6.9 .

The experiment was conducted in a 
randomized block design in split-plot arrangement with three plants per plot, and five replications, using three environments - protected environment of $10 \times$ $5 \mathrm{~m}$, with aluminum-based $50 \%$ reflective thermal screen (Aluminet $\left.{ }^{\mathbb{B}}\right)$, cold-water $\left(18\right.$ to $\left.20{ }^{\circ} \mathrm{C}\right)$ spraying, and white floor (E1); environment with full sun, cold-water spraying, and white floor (E2); environment with full sun, no cold-water spraying, and grey floor (E3) - in the plots, and five rates (R1 $=0.0, \mathrm{R} 2=500, \mathrm{R} 3=750, \mathrm{R} 4=1,000$, and R5 = $1,250 \mathrm{~mL} \mathrm{plant}^{-1}$ week $^{-1}$ ) of a cattle manure-based biofertilizer in the subplots.

The cold-water spraying was performed using a spray system with non-saline water, activated by a centrifugal pump, and controlled by a timer using water pulses; it was used for EI and E2 every hour, from $09: 30 \mathrm{~h}$ to $16: 30 \mathrm{~h}$, for 3 minutes, totaling 8 sprays per day.

The cattle manure-based biofertilizer was prepared with fresh cattle manure and water at 1:1 ratio, based on volume. This mixture was placed in a 500-liter box to be aerobically fermented for 20 days (VIANA et al., 2013). The chemical analysis of the biofertilizer presented $\mathrm{N}\left(0.82 \mathrm{~g} \mathrm{~L}^{-1}\right), \mathrm{P}\left(1.4 \mathrm{~g} \mathrm{~L}^{-1}\right), \mathrm{K}$ $\left(1.0 \mathrm{~g} \mathrm{~L}^{-1}\right), \mathrm{Ca}\left(2.5 \mathrm{~g} \mathrm{~L}^{-1}\right), \mathrm{Mg}\left(0.75 \mathrm{~g} \mathrm{~L}^{-1}\right)$ and $\mathrm{Na}$ $\left(0.28 \mathrm{~g} \mathrm{~L}^{-1}\right)$. The biofertilizer was applied weekly to all treatments (environments) from 15 days after transplanting (DAT) of the seedlings. A total of 15 applications were performed to meet the nutritional requirements of the crop, considering the maximum fertilization recommended for strawberry plants (SANTOS; MEDEIROS, 2003) - $180 \mathrm{~kg} \mathrm{ha}^{-1}$ of N, $300 \mathrm{~kg} \mathrm{ha}^{-1}$ of $\mathrm{P}_{2} \mathrm{O}_{5}$, and $100 \mathrm{~kg} \mathrm{ha}^{-1}$ of $\mathrm{K}_{2} \mathrm{O}$. Thus, the maximum recommended rate per plant ${ }^{-1}$ in the crop cycle was $14.4 \mathrm{~g}$ of $\mathrm{N}, 24 \mathrm{~g}$ of $\mathrm{P}_{2} \mathrm{O}_{5}$ and $8 \mathrm{~g}$ of $\mathrm{K}_{2} \mathrm{O}$.

The nutrient content in the substrate was estimate by multiplying the soil density $\left(1.3 \mathrm{~kg} \mathrm{dm}^{-3}\right)$ by the volume of soil placed into each pot $(10 \mathrm{~L})$, resulting in $13 \mathrm{~kg}$ of soil per pot. Thus, the substrate provided $0.16 \mathrm{~g} \mathrm{~kg}^{-1}$ of $\mathrm{N}, 0.11 \mathrm{~g} \mathrm{~kg}^{-1}$ of $\mathrm{P}$, and 0.34 $\mathrm{g} \mathrm{kg}^{-1}$ of $\mathrm{K}$, i.e., the total $\mathrm{N}, \mathrm{P}$, and $\mathrm{K}$ available to the plants before the application of the biofertilizer was $2.08 ; 1.43$, and $4.42 \mathrm{~g} \mathrm{~kg}^{-1}$, respectively; therefore, the nutritional needs of the plants were $12.32 \mathrm{~g}$ plant $^{-}$ ${ }^{1}$ of $\mathrm{N}, 22.57$ g plant $^{-1}$ of $\mathrm{P}$, and $3.42 \mathrm{~g} \mathrm{plant}^{-1}$ of $\mathrm{N}$.

A drip irrigation system with one dripper per plant and average flow of $1.6 \mathrm{~L} \mathrm{~h}^{-1}$ per emitter was used to apply the biofertilizer; the fertigation was controlled by valves at the beginning of each row.

The fertigation inside the protected environment was quantified using Equation 1:

$$
T i=\frac{L L i^{*} A V^{*} F a j}{E i * q_{v i}} \times 60
$$

wherein $T i$ is the fertigation duration ( $\min ), L L i$ is the liquid depth applied (mm); $A v$ is the pot area $\left(\mathrm{m}^{2}\right) ; F_{a j}$ is the adjustment factor 0.8 -internal divided by external water evaporation of USWB Class A tanks; $E i$ is the irrigation efficiency (0.90); and $q_{v}$ is the flow per pot $\left(\mathrm{L} \mathrm{h}^{-1}\right)$. The fertigation duration in the environments with full sun was quantified considering an adjustment factor $(F a j)$ of 1.0. The fertigation was performed daily and the water evaporation was measured in USWB Class A tanks installed at 30 meters from the experimental area.

Fruits that presented $75 \%$ ripening or redintense surface were harvested at 60 DAT (first crop season) and at 64 DAT (second crop season), following to the methodology proposed by Camargo et al. (2009). These fruits were counted and weighted using a precision scale to evaluate the number of fruits per plant (NFP), fruit weight (FW), and fruit yield (FY). NFP was quantified by the sum of the number of fruits divided by the number of plants of the plot; FY was represented by the average yield of fruits per area $\left(\mathrm{kg} \mathrm{ha}^{-1}\right)$ in each crop seasons; and FW was represented by the mean weight of fruits per plot of each crop season.

The post-harvest variables evaluated in the two crop seasons were: soluble solids (SS) content ( ${ }^{\circ}$ Brix), determined by the analyze of the juice manually extracted from the samples in a PAL-1 Digital Refractometer (ATAGO); and fruit diameter (FD), and fruit length (FL) measured using a digital caliper.

The data were subjected to analysis of variance by the $F$ test, the means of the plots (environments) were compared by the Tukey's test $(P<0.05)$, and the means of the subplots (biofertilizer rates) were subjected to regression equations, using the ASSISTAT. 7.6 Beta program.

\section{RESULTS AND DISCUSSION}

According to the analysis of variance, the interaction between the environments and biofertilizer rates was significant in the two crop seasons for fruit yield (FY). It was significant for fruit weight $(\mathrm{FW})$ only in the first crop season; and for number of fruits per plant (NFP) only in the second crop season (Table 2). 
Table 2. Analysis of variance and significance levels for number of fruits per plant (NFP), the average fruit mass (FM) and fruit yield (FY) of strawberry plants grown in different environments and fertilized with different rates of a cattle manurebased biofertilizer (BR) in two crop seasons (2013 and 2014).

\begin{tabular}{|c|c|c|c|c|c|c|c|}
\hline \multirow[b]{3}{*}{ Source of variation } & & \multicolumn{6}{|c|}{ Mean square } \\
\hline & \multicolumn{4}{|c|}{2013} & \multicolumn{3}{|c|}{2014} \\
\hline & $\mathrm{DF}$ & NFP & $\mathrm{FW}$ & FY & NFP & FW & FY \\
\hline Environments (A) & 2 & $75.57 * *$ & $3.561^{*}$ & $58.74 * *$ & $2.16^{\mathrm{ns}}$ & $1.98^{\mathrm{ns}}$ & $5.20 * *$ \\
\hline Residue (a) & 12 & 2.25 & 0.92 & 1.41 & 1.95 & 0.83 & 1.33 \\
\hline Plot & 14 & & & & & & \\
\hline $\mathrm{BR}(\mathrm{B})$ & 4 & $20.61^{\mathrm{ns}}$ & $3.52 * *$ & $3.77^{*}$ & $1.29^{\mathrm{ns}}$ & $1.60^{\mathrm{ns}}$ & $2.66^{\mathrm{ns}}$ \\
\hline A $x$ B interaction & 8 & $9.52^{\mathrm{ns}}$ & $2.08 *$ & $2.43^{*}$ & $2.34^{*}$ & $0.61^{\mathrm{ns}}$ & $8.99^{* *}$ \\
\hline Residue (b) & 48 & 9.31 & 0.9 & 5.1 & 1.8 & 1.74 & 1.14 \\
\hline Total & 74 & & & & & & \\
\hline CV A (\%) & & 28.76 & 26.89 & 20.25 & 27.87 & 15.99 & 25.6 \\
\hline CV B (\%) & & 29.44 & 26.11 & 29.17 & 29.01 & 24.25 & 22.46 \\
\hline
\end{tabular}

$\mathrm{DF}=$ degrees of freedom; $\mathrm{CV}=$ coefficient of variation; ${ }^{\mathrm{ns}}=$ not significant, $*=$ significant by the $\mathrm{F}$ test at $5 \%$ probability, $* *=$ significant by the $\mathrm{F}$ test at $1 \%$ probability.

The environment had independent effect on NFP (Figure 1). Plants in Environment 1 (E1) had higher NFP (5.7) than those in Environment 2 (E2) (3.56), and 3 (E3) (2.28). This result was may be due to the better control of leaf temperature by the plants, which optimized the photosynthetic activity, and turgidity., resulting in a better flowering, fruiting, and consequently, a high NFP (CHAVARRIA et al., 2012).

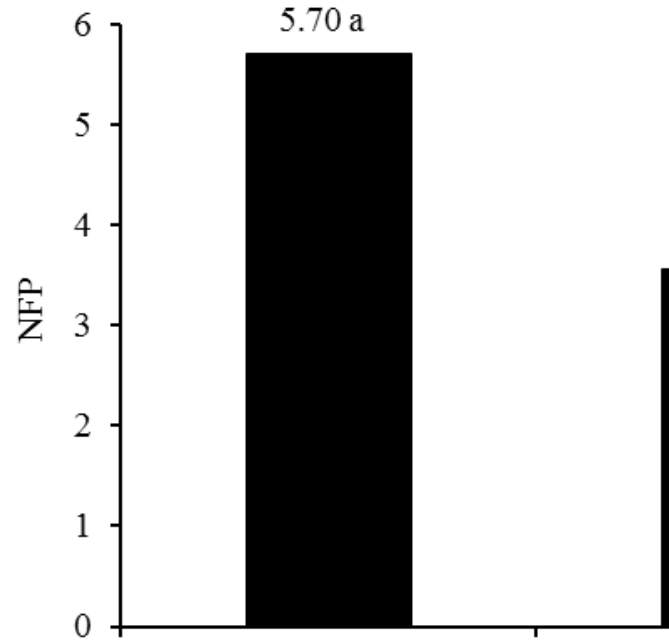

A1

\section{$3.56 \mathrm{~b}$}

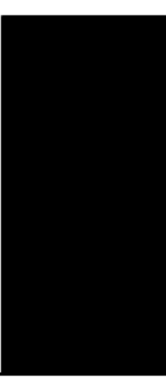

A2
$2.28 \mathrm{~b}$

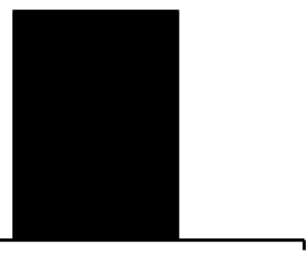

A3

\section{Environments}

Figure 1. Number of fruits per strawberry plant influenced by cultivated environments, $A 1=$ protected environment with screens, cold-water spraying, and white floor; A2 = environment with full sun, cold-water spraying, and white floor; A3 = environment with full sun, no cold-water spraying, and grey floor.

The lower fruit production found in E2 and E3 were similar to that reported by Andriolo et al. (2010), who explained this result by the abortion of strawberry flowers due to high temperatures. Dias et al. (2015) evaluated strawberry crops in a mountain region in the state of Ceará, Brazil, which has average temperatures of $27.1^{\circ} \mathrm{C}$, and found a higher NFP (10.96).

The interaction between environments and biofertilizer rates was significant in the second crop season for NFP. The NFP of plants grown in E3 fitted to a linear model, and plants in soils with no biofertilizer had a maximum NFP of 2.5. The NFP of plants grown in E1 and E2 fitted to a quadratic polynomial model; the biofertilizer rate of 583.33 $\mathrm{mL}$ plant $^{-1}$ week $^{-1}$ resulted in a maximum NFP of $5.37(\mathrm{E} 1)$, and the rate of $650 \mathrm{~mL}$ plant $^{-1}$ week $^{-1}$ resulted in a maximum NFP of 3.68 (E2) (Figure 2). 


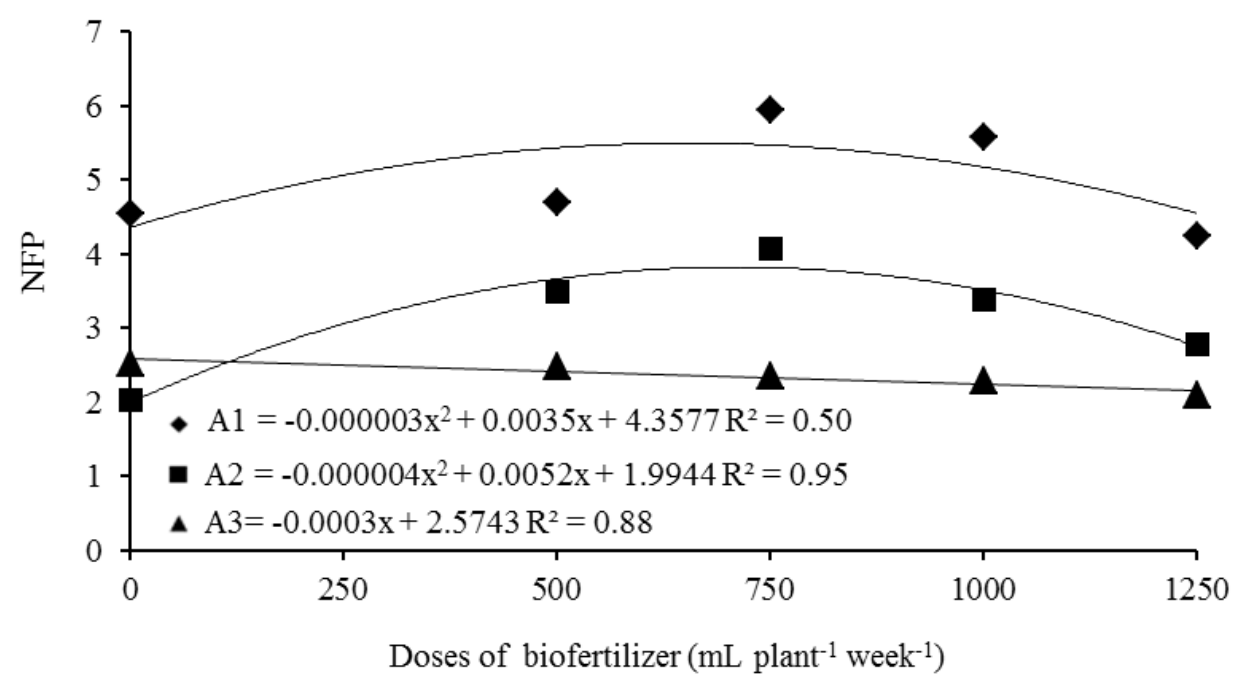

Figure 2. Number of fruits per plant of strawberry as a function of the doses of bovine biofertilizer cultivated in protected environment protected environment of the screened type, protected environment with screens, cold-water spraying, and white floor - A1 ( ), environment with full sun, cold-water spraying, and white floor - A2 (๘) and environment with full sun, no cold-water spraying, and grey floor - A3 $(\boldsymbol{\Delta})$.

Higher NFP were reported by Vignolo et al. (2011), who evaluated production of strawberry plants of the cultivar Camarosa under full sun conditions and found 43.6 fruits plant ${ }^{-1}$; and by Pires et al. (2007) who evaluated NFP of strawberry plants under protect environment and found 85.7 fruits plant $^{-1}$. However, these expressively higher NFP were found in experiments conducted in regions with more favorable climatic conditions to this cropaverage temperatures of $22{ }^{\circ} \mathrm{C}$, and air relative humidity of $76 \%$.

The low fruit production found in the coast of the state of Ceará, Brazil, was probably due to the high temperatures (average of $28.2^{\circ} \mathrm{C}$ ) of this region, which generated a stressful environment, causing floral abscission and, consequently, reduction of number of fruits (LEDESMA et al., 2008). Sousa et al. (2014) performed an experiment under the same climatic conditions of the present study and found higher NFP for strawberry plants of the cultivars Oso Grande (9.5 fruits plant ${ }^{-1}$ ) and Verão (6.45 fruit plant $^{-1}$ ) grown under full sun (average temperature of $26.2^{\circ} \mathrm{C}$ ) conditions.

The interaction between the environments and biofertilizer rates was significant for fruit weight (FW) only in the first season (Figure 3); the FW data in E1 and E2 fitted to a positive linear model, and those of E3 fitted to a negative linear model.

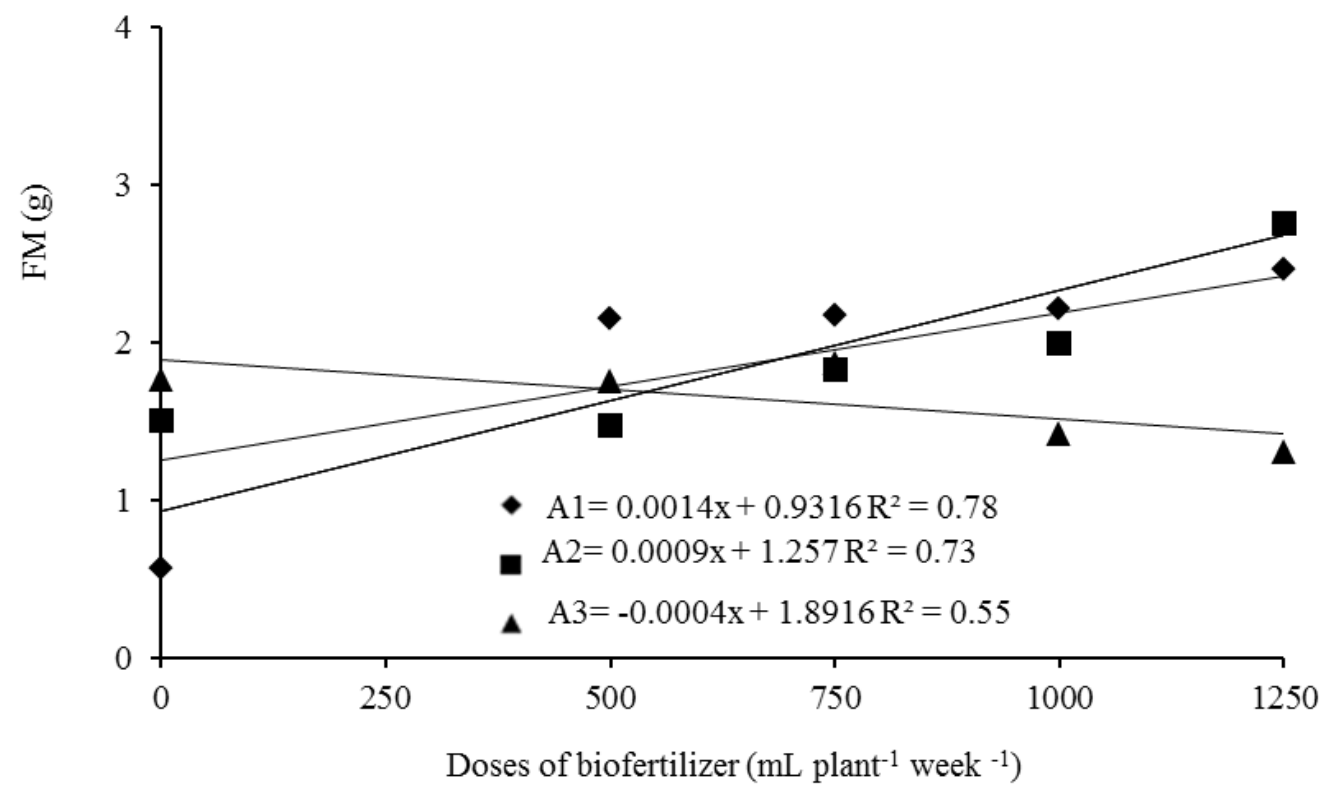

Figure 3. Average mass of fruits per plan of strawberry as a function of the doses of bovine biofertilizer, in protected environment protected environment of the screened type, protected environment with screens, cold-water spraying, and white floor - A1 ( ), environment with full sun, cold-water spraying, and white floor - A2 (®) and environment with full sun, no cold-water spraying, and grey floor - A3 $(\boldsymbol{\Lambda})$. 
FW increased in E1 and E2, and decreased in E3, probably due to the temperature of the environments, i.e., the lower the temperature the lower the plants' metabolic expense and, consequently, the greater the amount of photoassimilates to the fruits. Moreover, high temperatures directly affect stomatal closure, reducing absorption of nutrients and fruit weight.

A high nutrient intake allows high photosynthetic rates and, consequently, large amount of carbohydrates allocated to reserve organs of plants, resulting in heavier fruits (SOUSA et al., 2013). Contrastingly, Dias et al. (2015) found no significant effects for strawberry FW when evaluating different biofertilizer rates in full sun, and screened protected environments. However, according to Sousa et al. (2014), the FW of strawberry plants of the Oso Grande cultivar in a similar environment to E1 of the present study were similar to that found in the environment with full sun.

In Figure 4A and 4B the regression analyses for the data of total fruit yield (FY) as a function of the interaction between the environments and biofertilizer rates showed a quadratic polynomial model for the first season, with the highest yields of $10.15 \mathrm{Mg} \mathrm{ha}^{-1}$ with a biofertilizer rate of $378.57 \mathrm{~mL}$ plant $^{-1}$ week $^{-1}(\mathrm{E} 1)$; $4.62 \mathrm{Mg} \mathrm{ha}^{-1}$ with a biofertilizer rate of $576.16 \mathrm{~mL}$ plant $^{-1}$ week $^{-1}$ (E2); and $2.95 \mathrm{Mg}$ $\mathrm{ha}^{-1}$ with a biofertilizer rate of $750 \mathrm{~mL}$ plant $^{-1}$ week $^{-1}$ (E3). The data of FY in E1 and E2 fitted to a quadratic model in the second season, with maximum yields of $6.49 \mathrm{Mg} \mathrm{ha}^{-1}$ with a biofertilizer rate of $500 \mathrm{~mL}_{\text {plant }}{ }^{-1}$ week $^{-1}$ (E1), and $4.65 \mathrm{Mg} \mathrm{ha}^{-1}$ with a biofertilizer rate of $325 \mathrm{~mL}$ plant $^{-1}$ week $^{-1}$ (E2); and the data of FY in E3 in the second season fitted to a negative linear model, with a maximum yield of $2.52 \mathrm{Mg} \mathrm{ha}^{-1}$ with no biofertilizer.

The results showed an increase in FY from the first to the second crop season; this can be due to the occurrence of lower temperatures in the second season, which improved the plant development and, consequently, fruit yield. The air temperature of the experimental area affects the potential flowering of strawberry plants; since it affects the speed of biochemical reactions, and internal processes of sap transport (RESENDE et al., 2010).
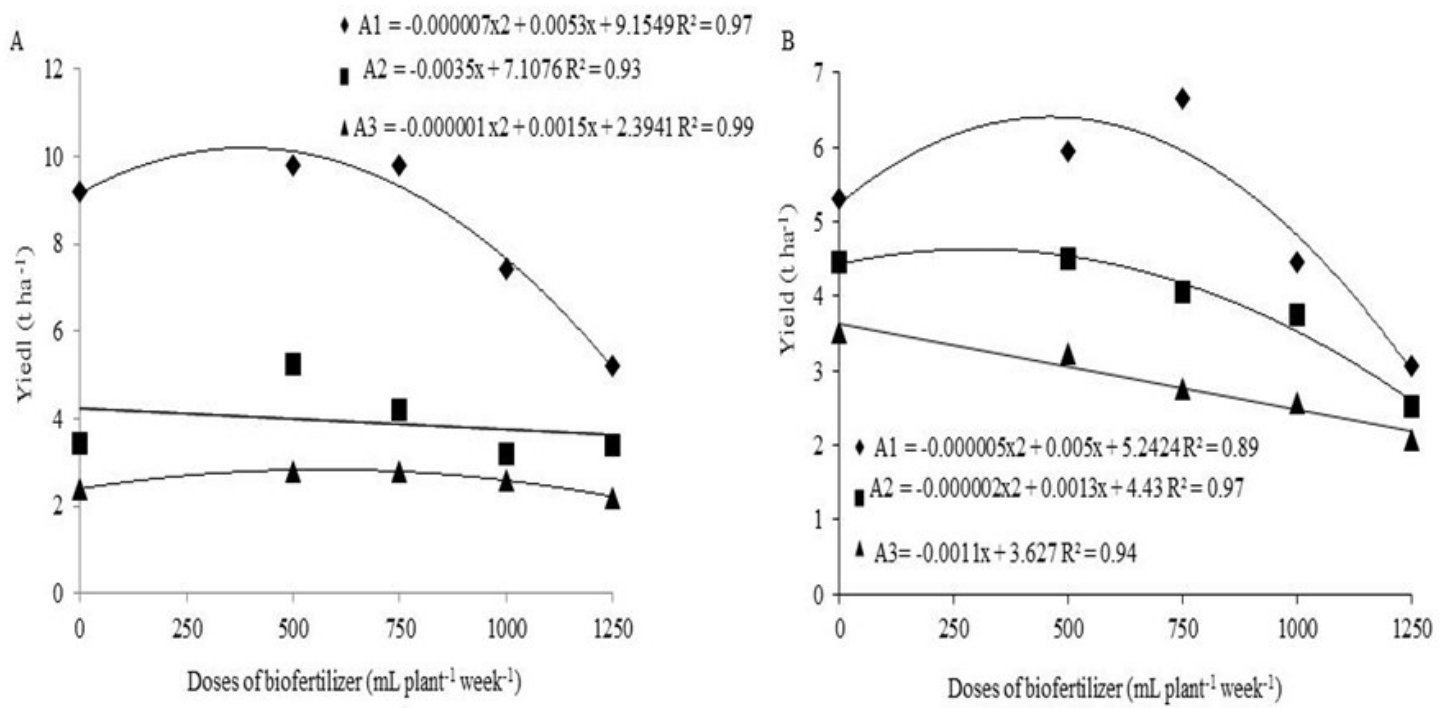

Figure 4. Yield per plan of strawberry as a function of the doses of bovine biofertilizer, in protected environment protected environment of the screened type, protected environment with screens, cold-water spraying, and white floor - A1 ( $\bullet$ ), environment with full sun, cold-water spraying, and white floor - A2 (๘) and environment with full sun, no cold-water spraying, and grey floor - A3 ( $\mathbf{\Delta})$.

Studies conducted under similar climatic conditions with the same strawberry cultivar (Oso Grande) showed variable results of FY; Sousa et al. (2014) found FY of $3.2 \mathrm{Mg} \mathrm{ha}^{-1}$ when this cultivar were grown under full sun and Lima (2014) reported a FY of $6.7 \mathrm{Mg} \mathrm{ha}^{-1}$ for plants under protected environment. Dias et al. (2015) studied this same cultivar under the climatic conditions of Redenção, $\mathrm{CE}$, Brazil, and found $10.7 \mathrm{Mg} \mathrm{ha}^{-1}$; however, these values are well below those found in some experiments performed in the South and Southeast regions of Brazil. According to Filgueira (2012), the strawberry FY in Brazil can reach $80 \mathrm{Mg} \mathrm{ha}^{-1}$ when crops are well managed, in areas with favorable climatic conditions, and using adapted cultivars.

According to the analysis of variance (Table 3), no significant interaction between environments and biofertilizer rates were found for fruit length (FL), fruit diameter (FD), and soluble solids (SS) content in the first crop season. However, in the second crop season, this interaction was significant for FL and FD at 5\% level of significance. 
Table 3. Analysis of variance and levels of significance for fruit length (FL), fruit diameter (FD), and soluble solids (SS) content of strawberry plants grown in different environments and fertilized with different rates of cattle manure-based biofertilizer (BR) in two crop seasons (2013 and 2014).

\begin{tabular}{|c|c|c|c|c|c|c|c|}
\hline \multirow[b]{3}{*}{ Sources of variation } & \multirow[b]{3}{*}{$\mathrm{DF}$} & \multicolumn{6}{|c|}{ Mean square } \\
\hline & & \multicolumn{3}{|c|}{2013} & \multicolumn{3}{|c|}{2014} \\
\hline & & FL & FD & SS & FL & FD & SS \\
\hline Environments (A) & 2 & $156.87^{\mathrm{ns}}$ & $204.82^{\mathrm{ns}}$ & $37.83 * *$ & $38.38 * *$ & $22.77 *$ & $3.16^{\mathrm{ns}}$ \\
\hline Residue (a) & 12 & 7.84 & 3.52 & 1.76 & 4.83 & 4.87 & 0.96 \\
\hline Plots & 14 & & & & & & \\
\hline $\mathrm{BR}(\mathrm{B})$ & 4 & $49.40^{* *}$ & $25.77 * *$ & $4.01^{\mathrm{ns}}$ & $4.37^{\mathrm{ns}}$ & $2.12^{\mathrm{ns}}$ & $1.67^{\mathrm{ns}}$ \\
\hline A $\times \mathrm{B}$ interaction & 8 & $14.55^{\mathrm{ns}}$ & $6.85^{\mathrm{ns}}$ & $3.47^{\mathrm{ns}}$ & $5.41 *$ & $6.40 *$ & $1.30^{\mathrm{ns}}$ \\
\hline Residue (b) & 48 & 11.41 & 4.34 & 3.11 & 2.38 & 2.39 & 1.06 \\
\hline Total & 74 & & & & & & \\
\hline CV A (\%) & & 12.56 & 10.36 & 16.19 & 8.27 & 11.33 & 11.83 \\
\hline CV B (\%) & & 15.15 & 11.5 & 23.51 & 5.8 & 7.94 & 12.44 \\
\hline
\end{tabular}

$\mathrm{DF}=$ degrees of freedom; $\mathrm{CV}=$ coefficient of variation; ${ }^{\mathrm{ns}}=$ not significant, $*=$ significant by the $\mathrm{F}$ test at $5 \%$ probability, ${ }^{* *}=$ significant by the $\mathrm{F}$ test at $1 \%$ probability.

In Figure 5 one can the biofertilizer rate had independent effect on FL in the first crop season, with data fitting to a positive linear model, and the highest FL $(25 \mathrm{~mm})$ found with a biofertilizer rate of $1,250 \mathrm{~mL}$ plant $^{-1}$ week $^{-1}$. These results may be due to the greater supplying of nutrients by the higher biofertilizer rate. A good nutritional condition allows a better crop development and fruit yield (SOUSA et al., 2013; VIANA et al., 2013).

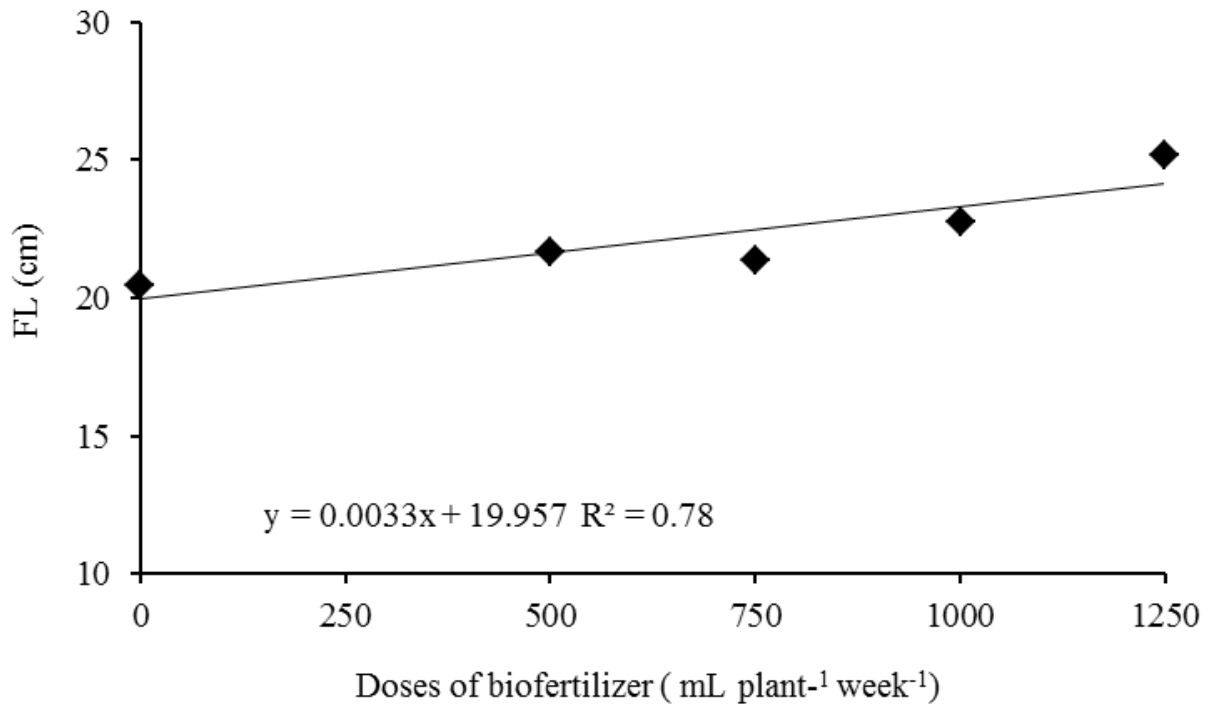

Figure 5. Fruit length due to the different doses of bovine biofertilizer.

Contrastingly, Dias et al. (2015) found a decreased in FL with increasing rates of a cattle manure-based biofertilizer for plants of the Oso Grande cultivar grown in the climatic conditions of Redenção, Ceará.

In Figure 6 it is observed that the interaction between environments and biofertilizer rates was significant for FL in the second crop season. The FL data of the tree environments evaluated fitted to a quadratic polynomial model; however, the highest FL found were $29.22 \mathrm{~mm}$ in E1 with a biofertilizer rate of $585 \mathrm{~mL}_{\text {plant }}{ }^{-1}$ week $^{-1} ; 25.04 \mathrm{~mm}$ in E2 with a rate of $370 \mathrm{~mL}$ plant $^{-1}$ week $^{-1}$; and $27.22 \mathrm{~mm}$ in E3 with a rate of $466.67 \mathrm{~mL}_{\text {plant }}{ }^{-1}$ week $^{-1}$. 


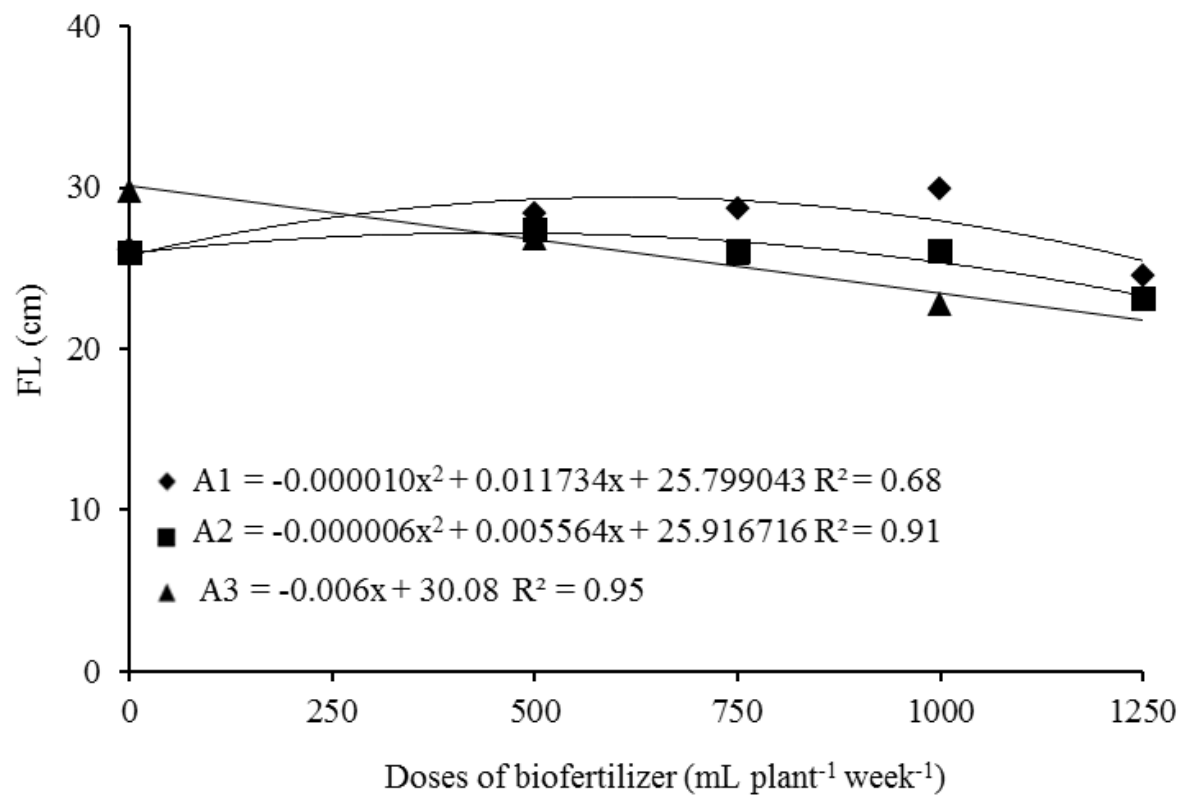

Figure 6. Fruit length as a function of the doses of bovine biofertilizer, in protected environment protected environment of the screened type, protected environment with screens, cold-water spraying, and white floor - A1 ( $\downarrow)$, environment with full sun, cold-water spraying, and white floor - A2 (-) and environment with full sun, no cold-water spraying, and grey floor A3 $(\boldsymbol{\Delta})$.

Dias et al. (2015) evaluated strawberry crops in greenhouse and in field conditions subjected to increasing cattle manure-based biofertilizer rates and found higher FL in plants grown in field conditions. Yuri et al. (2012) evaluated the strawberry cultivar Oso Grande grown with different types of mulching in the state of Minas Gerais, Brazil, and found FL of $29.1 \mathrm{~mm}$-higher than that found in the present work.
The model that best fitted to a positive linear model as a function of the biofertilizer rates in the first crop season (Figure 7). According to Pinto et al. (2008), the application of organic products to agricultural soils is important because of their diverse mineral nutrients and positive action as enzymatic activator of plant metabolism, which can contribute to a larger fruit diameter.

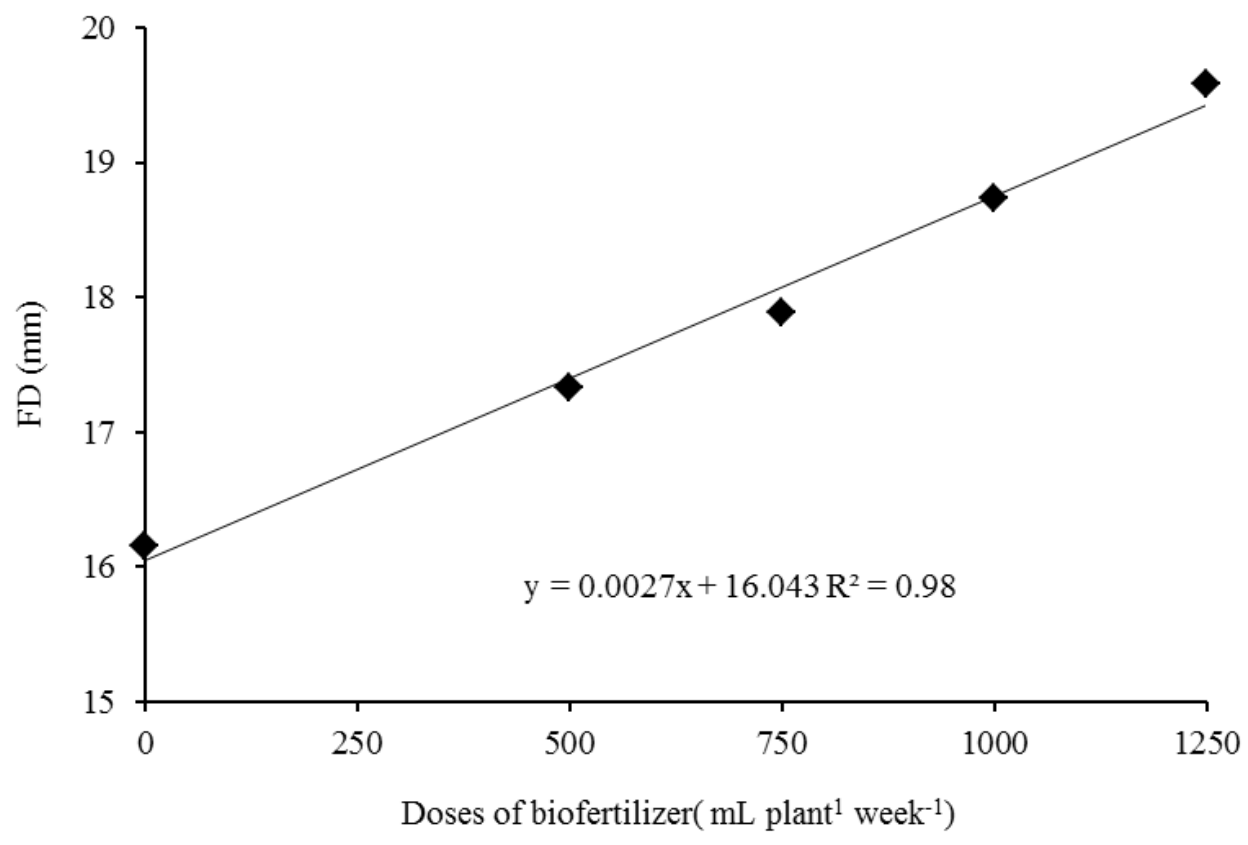

Figure 7. Fruit diameter due to the different doses of bovine biofertilizer. 
The result for FD found by Lima (2014) (21.0 $\mathrm{mm}$ ) was similar to that found in the present work; they evaluated strawberry plants grown with a cattle manure-based biofertilizer under the same climatic conditions. However, Dias et al. (2015) found no significant changes in FD of strawberry fruits with increasing rates of this same biofertilizer.

In Figure 8, the biofertilizer rates and its interaction with the environments affected the FD in the second cycle. The mathematical models showed largest FD $(21.46 \mathrm{~mm})$ in plants in E1 with the rate of $620 \mathrm{~mL}$ plant $^{-1}$ week $^{-1}$; fruits in $\mathrm{E} 2$ presented similar FD with increasing biofertilizer rates; and fruits in E3 had the largest FD $(20.05 \mathrm{~mm})$ with a biofertilizer rate of $330 \mathrm{~mL}$ plant $^{-1}$ week $^{-1}$.

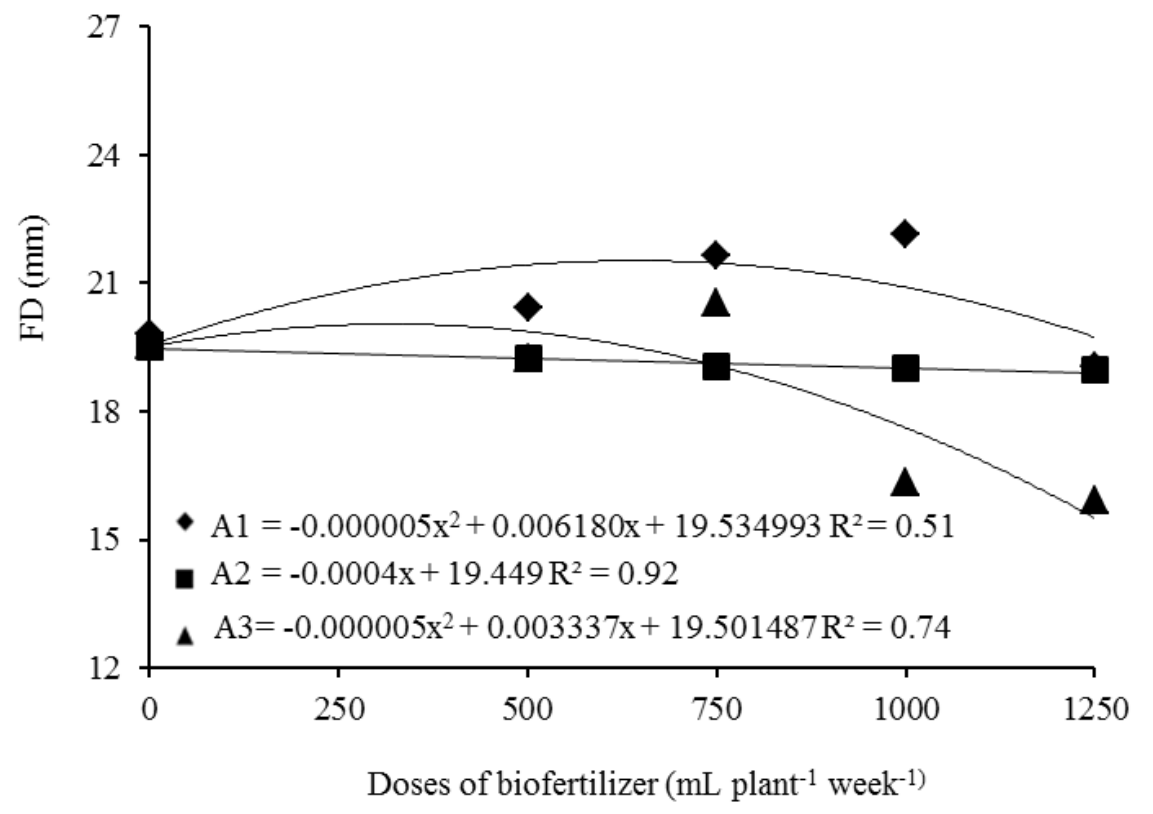

Figure 8. Fruit diamanter as a function of the doses of bovine biofertilizer, in protected environment protected environment of the screened type, protected environment with screens, cold-water spraying, and white floor - A1 ( $\downarrow)$, environment with full sun, cold-water spraying, and white floor - A2 (๘) and environment with full sun, no cold-water spraying, and grey floor - A3 ( $\mathbf{\Delta})$.

Similarly, Rodrigues et al. (2009) reported a positive increase of longitudinal diameter in passion fruit (Passiflora edulis $f$. flavicarpa Dg.) fruits using a Brazilian biofertilizer formula known as Supermagro. Moreover, Silva et al. (2016) found positive FD response of fig (Ficus carica L.) plants grown under protected environment, and full sun conditions to a cattle manure-based biofertilizer.

The soluble solids (SS) contents of fruits in E2 (8.54 ${ }^{\circ}$ Brix) and E3 (9.2 ${ }^{\circ}$ Brix) were statistically similar by the Tukey's test in the first crop season, but they were higher than that of fruits in E1 (6.82 ${ }^{\circ}$ Brix) (Figure 9). The SS of fruits of all environments were similar in the second crop season.

The plants grown under full sun had higher ${ }^{\circ}$ Brix than those grown under protected environment, differing from the results of Resende et al. (2010) who found $6.9,6.2$, and $5.6{ }^{\circ}$ Brix for strawberries grown in high tunnel greenhouse, low tunnel greenhouse, and full sun conditions, respectively. The ${ }^{\circ}$ Brix found by Dias et al. (2015) (6.77) was similar to that found in the present work in the protected environment for the same cultivar; however, they found lower ${ }^{\circ}$ Brix (7.8) in fruits grown under full sun conditions. 


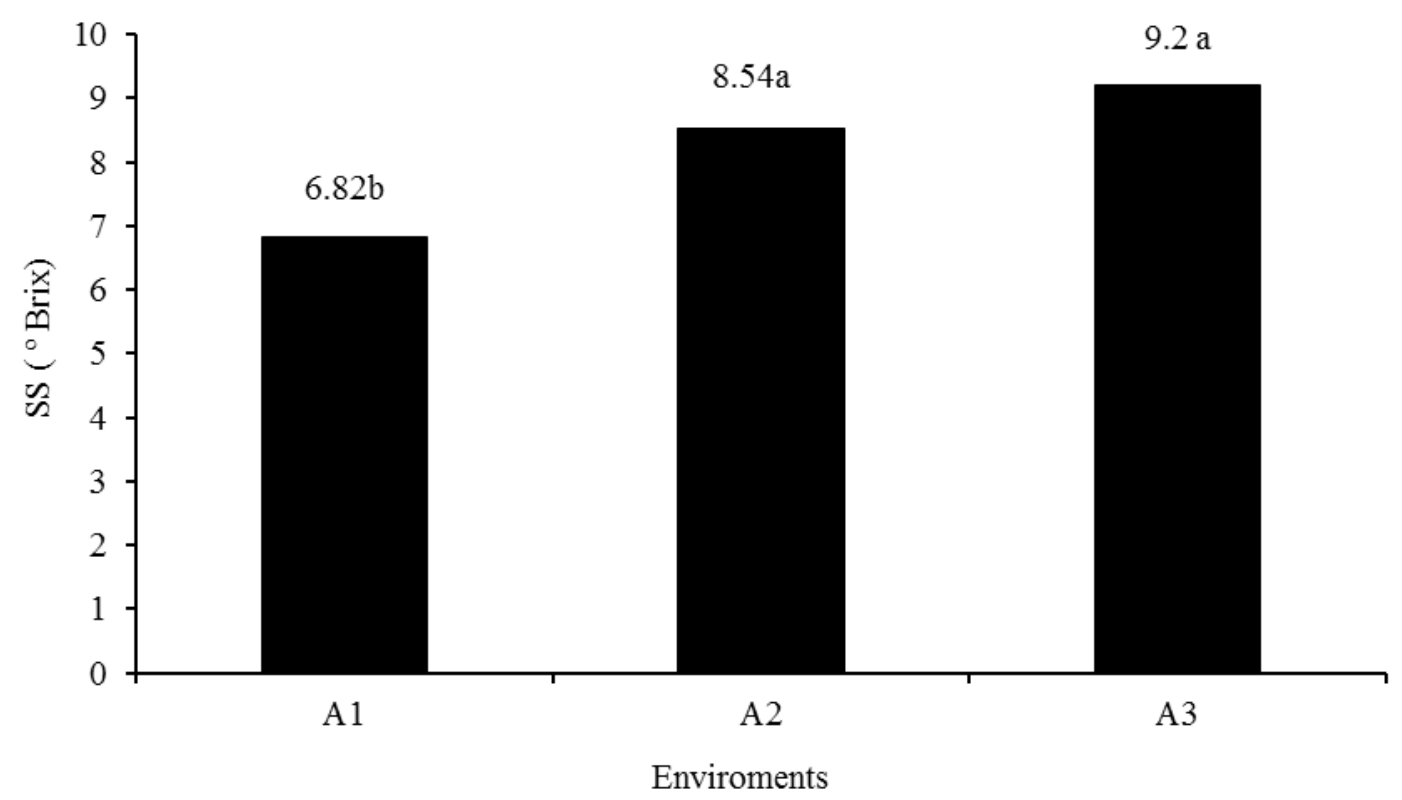

Figura 9. Soluble solids in plant plants influenced by growing environments, A1 = protected environment with screens, cold-water spraying, and white floor; A2 = environment with full sun, cold-water spraying, and white floor; A3 = environment with full sun, no cold-water spraying, and grey floor.

\section{CONCLUSIONS}

Plants grown under screened protected environment, with cold-water spraying, and white floor presented the greatest number of strawberry fruits per plant in both first (2013) and second (2014) crop seasons.

The application of the cattle manure-based biofertilizer at rate of $1,250 \mathrm{~mL}$ plant $^{-1}$ week $^{-1}$ resulted in higher fruit weights when plants were grown in environment with full sun, cold-water spraying, and white floor (second crop season).

The strawberry fruit yield was higher when the plants were grown under protected environment with a biofertilizer rate of $500 \mathrm{~mL}$ plant $^{-1}$ week $^{-1}$ (first crop season) and $325 \mathrm{~mL} \mathrm{plant}^{-1}$ week $^{-1}$ (second crop season).

The highest fruit diameter and length in the first crop season was found using a biofertilizer rate of 1,250 mL plant $^{-1}$ week $^{-1}$.

In the second crop season, the highest fruit length was found with a biofertilizer rate of 585 plant $^{-1}$ week $^{-1}$, and the highest fruit diameter was found with a rate of $620 \mathrm{~mL}_{\text {plant }}{ }^{-1}$ week $^{-1}$, in plants grown under protected environment.

Plants grown in the environment with full sun, no cold-water spraying, and gray floor presented fruits with better soluble solid contents ( ${ }^{\circ} \mathrm{Brix}$ ) than those in the protected environment, and the environment with full sun and cold-water spraying.

\section{REFERENCES}

ANDRIOLO, J. L. et al. Doses de potássio e cálcio no crescimento da planta, na produção e na qualidade de frutas do morangueiro em cultivo sem solo. Ciência Rural, v. 40, n. 2, p. 267-272, 2010.

COSTA, R. C. et al. Telas de sombreamento na produção de morangueiro em ambiente protegido. Horticultura Brasileira, v. 29, n. 1, p. 98-102, 2011.

CAMARGO, L. K. P. et al. Caracterização química de frutos de morangueiro cultivados em vasos sob sistemas de manejo orgânico e convencional. Semina, v. 30, Sup., p. 993-998, 2009.

CAMARGO, L. K. P. et al. Desempenho produtivo e massa média de frutos de morangueiro obtidos de diferentes sistemas de cultivo. Ambiência, v. 6, n. 2, p. 2281-288, 2010.

CHAVARRIA, G. et al. Caracterização fenológica e requerimento térmico da cultivar Moscato Giallo sob cobertura plástica. Revista Brasileira de Fruticultura, v. 31, n. 1, p. 119-126, 2012.

HENZ, G. P. Desafios enfrentados por agricultores familiares na produção de morango no Distrito Federal. Horticultura Brasileira, v. 28, n. 3, p. 260$265,2010$.

DIAS, C. N. et al. Produtividade e qualidade do morangueiro sob dois ambientes e doses de 
biofertilizante. Revista Brasileira de Engenharia Ambiental, v. 19, n. 10, p. 961-966, 2015.

FILGUEIRA, F. A. R. Novo manual de olericultura. 2 ed. Viçosa, MG: UFV, 2012. 421 p.

LEDESMA, N. A.; NAKATA, M.; SUGIYAMA, N. Effect of high temperature stress on the reproductive growth of strawberry cvs. 'Nyoho' and 'Toyonoka'. Scientia Horticulturae, v. 116, n. 2, p. 186-193, 2008.

LIMA, F. A. Cultivo de morango em ambiente tipo telado, sob manejos diferenciados deirrigação e de fertilização orgânica, nas condições climáticas de Fortaleza, Ceará. 2014. 70 f. Dissertação (Mestrado em Engenharia Agrícola: Área de concentração em irrigação e drenagem) Universidade Federal do Ceará, Fortaleza, 2014.

MAZARO, S. M. et al. Produção e qualidade de morangueiro sob diferentes concentrações de calda bordalesa, sulfocálcica e biofertilizante supermagro. Semina, v. 34, n. 2, p. 3285-3294, 2013.

OLIVEIRA, R. P.; SCIVITTARO, W. B. Desempenho produtivo de mudas nacionais $\mathrm{e}$ importadas de morangueiro. Revista Brasileira de Fruticultura, v. 28, n. 3, p. 520-522, 2006.

PINTO, J. M. et al. Cultivo orgânico do meloeiro com aplicação de biofertilizantes e doses de substância húmica via fertirrigação. Revista Ceres, v. 55, n. 4 , p. $280-286,2008$.

PIRES, R. C. M. et al. Produção do morangueiro em diferentes níveis de água, coberturas do solo e ambiente de cultivo. Irriga, v. 12, n. 3, p. 338-353, 2007.

REIS, L. S. et al. Componentes da radiação solar em cultivo de tomate sob condições de ambiente protegido, Revista Brasileira de Engenharia Agrícola e Ambiental, v. 16, n. 7, p. 739-744, 2012.

REISSSER JÚNIOR, C. et al. Panorama do cultivo de morangos no Brasil. 2015. Disponível em: http:// www.revistacampoenegocios.com.br/panorama-docultivo-de-morangos-no-brasil/. Acesso em: 29 out. 2017.

RESENDE, J. T. V. et al. Produtividade e teor de sólidos solúveis de frutos de cultivares de morangueiro em ambiente protegido. Horticultura Brasileira, v. 28, n. 2, p. 185-189, 2010.

RODRIGUES, A. C. et al. Produção e nutrição mineral do maracujazeiro-amarelo em solo com biofertilizante supermagro e potássio. Revista Brasileira de Engenharia Agrícola e Ambiental, v. 13, n. 2, p. 117-124, 2009.

SANTOS, A. M. Cultivares. In: SANTOS, A. M., MEDEIROS, A. R. M. (Eds.). Morango: produção. Brasília: Embrapa Informação Tecnológica, 2003. p. 24-30.

SOUSA, G. G. et al. Fertirrigação com biofertilizante bovino: Efeitos no crescimento, trocas gasosas e na produtividade do pinhão-manso. Revista Brasileira de Ciências Agrárias, v. 8, n. 3, p. 503-509, 2013.

SOUSA, G. G. et al. Fertirrigação potássica na cultura do morango no litoral Cearense, Bragantia, v. 73, n. 1, p. 1-6, 2014.

SILVA, F. L. et al. Yield of common fig fertigated with bovine biofertilizer in the semiarid region of ceará. Revista Caatinga, v. 29, n. 2, p. 425-434, 2016.

VIANA, T. V. A. et al. Trocas gasosas e teores foliares de NPK em meloeiro adubado com biofertilizantes. Revista Brasileira de Ciências Agrárias, v. 8, n. 4, p. 595-601,2013.

VIANA, T. V. A. et al. Growth, gas exchange and yield of corn when fertigated with bovine biofertilizer. Revista Caatinga, v. 27, n. 3, p. 106114,2014

VIGNOLO, K. G. et al. Produção de morangos a partir de fertilizantes alternativos em pré-plantio. Ciência Rural, v. 41, n. 10, p. 1755-1761, 2011.

YURI, E. J. et al. Cultivo de morangueiro sob diferentes tipos de mulching. Horticultura Brasileira, v. 30, n. 3, p. 424-427, 2012. 